\title{
Amphipod and sea urchin tests to assess the toxicity of Mediterranean sediments: the case of Portmán Bay*
}

\author{
A. CESAR ${ }^{1,2}$, A. MARÍN ${ }^{1}$, L. MARÍN-GUIRAO ${ }^{1}$ and R. VITA ${ }^{1}$ \\ ${ }^{1}$ Departamento de Ecología e Hidrología, Facultad de Biología, Universidad de Murcia, 30100 Murcia. Spain. \\ E-mail: arnaldo@um.es \\ ${ }^{2}$ Departamento de Ecotoxicologia, Universidade Santa Cecilia, Rua Owaldo Cruz, 266, 11045-907, Santos, SP, Brazil.
}

\begin{abstract}
SUMMARY: The sediment formed by the tailings of an abandoned mine, which discharged into Portmán Bay, Murcia, SESpain, was tested to establish a possible gradient of heavy metals. The results were compared with tolerance limits of what was calculated from control sites. Whole sediment toxicity tests were performed on two amphipod species, Gammarus aequicauda and Microdeutopus gryllotalpa, while sediment-water interface and porewater toxicity tests were performed on three sea urchins species, Arbacia lixula, Paracentrotus lividus and Sphaerechinus granularis. The sensitivity of these marine organisms was evaluated by exposure tests using the reference substances: ammonium chloride $\left(\mathrm{NH}_{4} \mathrm{Cl}\right)$, cadmium chloride $\left(\mathrm{CdCl}_{2}\right)$, potassium dichromate $\left(\mathrm{K}_{2} \mathrm{Cr}_{2} \mathrm{O}_{7}\right)$, sodium dodecyl sulfate $\left(\mathrm{C}_{12} \mathrm{H}_{25} \mathrm{NaO}_{4} \mathrm{~S}\right)$ and zinc sulfate $\left(\mathrm{ZnSO}_{4}\right)$. The concentration of heavy metals decreased along the pollution gradient. Amphipod 10 day acute toxicity tests clearly demonstrated the gradient of toxicity. The sediment-water interface tests conducted with sea urchins also pointed to a pollution gradient and were more sensitive than the tests involving amphipods.
\end{abstract}

Key words: amphipods, sea urchins, toxicity; sediment-water interface, pollution.

RESUMEN: ENSAYOS CON ANFÍPODOS Y ERIZOS DE MAR PARA EVALUAR LA TOXICIDAD DE SEDIMENTOS MEDITERRÁNEOS: EL CASO DE LA BAHÍA DE PORTMÁN. - Los sedimentos formados por los estériles de una mina abandonada, que fueron descargados en la bahía de Portmán, Murcia, SE de España, fueron sometidos a ensayos para establecer un posible gradiente de metales pesados. Se realizaron ensayos de toxicidad total de los sedimentos en dos especies de anfípodos, Gammarus aequicauda y Microdeutopus gryllotalpa, mientras que se realizaron ensayos de toxicidad de la interfase sedimento-agua y del agua intersticial en tres especies de erizos de mar, Arbacia lixula, Paracentrotus lividus y Sphaerechinus granularis. La sensibilidad de estos organismos marinos se evaluó mediante ensayos de exposición que utilizaban las siguientes sustancias de referencia: cloruro amónico $\left(\mathrm{NH}_{4} \mathrm{Cl}\right)$, cloruro de cadmio $\left(\mathrm{CdCl}_{2}\right)$, dicromato potásico $\left(\mathrm{K}_{2} \mathrm{Cr}_{2} \mathrm{O}_{7}\right)$, dodecil sulfato de sodio $\left(\mathrm{C}_{12} \mathrm{H}_{25} \mathrm{NaO}_{4} \mathrm{~S}\right)$ y sulfato de zinc $\left(\mathrm{ZnSO}_{4}\right)$. La concentración de metales pesados disminuyó a lo largo del gradiente de contaminación. Los ensayos de toxicidad aguda durante 10 días demostraron claramente el gradiente de toxicidad. Los ensayos de interfase sedimento-agua realizados con los erizos de mar también indicaron un gradiente de contaminación y fueron más sensitivos que los ensayos con anfípodos.

Palabras clave: anfípodos, erizos de mar, toxicidad, interfase sedimento-agua, contaminación.

\section{INTRODUCTION}

Sediment provides a habitat for many marine organisms and is a major deposit of the more persistent chemicals that are introduced into waters from

*Received January 23, 2002. Accepted April 19, 2003. diverse sources (Ingersoll, 1995). Infaunal amphipods are excellent for short term toxicity tests involving whole sediment and are strongly recommended as appropriate test species for acute toxicity tests in marine and estuarine waters (U.S. EPA, 1994; ASTM, 1997). Echinoderm embryo-larval development tests have been widely used to characterize a 
variety of toxicants, including sediment elutriate, solid phase and interstitial water (Bryn et al., 1998). The composition of interstitial water is considered a useful indicator of sediment toxicity, although the exact pathway of contaminant uptake by aquatic organisms is not fully understood (Van Den Berg et al., 1984). Generally, amphipods and echinoderms constitute an ideal tool for marine ecotoxicological tests (Gannon and Beeton, 1971; Swartz et al., 1982; Nipper et al., 1993; Carr et al., 1996; Del Valls et al., 1998; Cesar et al. 2000; Hunt et al., 2001a, b). For marine pollution studies, experiments involving sea urchin eggs and embryos are straightforward, rapid and extremely sensitive, providing results of great uniformity and accuracy. In general, such experiments have been accepted internationally as appropriate for toxicity tests (U.S. EPA, 1995; Environment Canada, 1997; CETESB, 1999).

We studied the sediments from Portmán Bay (Fig.1), using Mediterranean species of amphipods and sea urchins. Portmán Bay is a natural harbor known in Roman times as Portus Magnus, where lead was shipped for use throughout the Roman Empire. The surrounding mountains, which are rich in heavy metals, contain numerous old Roman lead workings. Much later, from 1960 to 1991, the Peñarroya mine pumped 6-8 thousand tons of tailings per day directly into the sea. In total, approximately 11 million $\mathrm{m}^{3}$ of mine tailings were dumped into Portmán Bay during this period. The tailings contained calcite, dolomite, pyrite, sulfides of $\mathrm{Cd}, \mathrm{Cu}, \mathrm{Pb}$ and $\mathrm{Zn}$, and some aluminum and silica minerals. The active disposal area extended beyond the continental shelf through a submarine canyon. The mines were abandoned in 1991, leaving about 80 hectares of sediments to fill up the bay, where it is possible to walk over the mine-waste. The objective of our study was to characterize the nature and extent of metal pollution and the toxicity of the sediment deposits. For this, we studied the physical and chemical characteristics of the sediments, and the toxicity of porewater and sediment-water interface on marine invertebrates. The results are discussed in relation to the different test species used.

\section{MATERIALS AND METHODS}

\section{Sample collection and processing}

Replicate sediment samples were collected from four points along the expected gradient of heavy

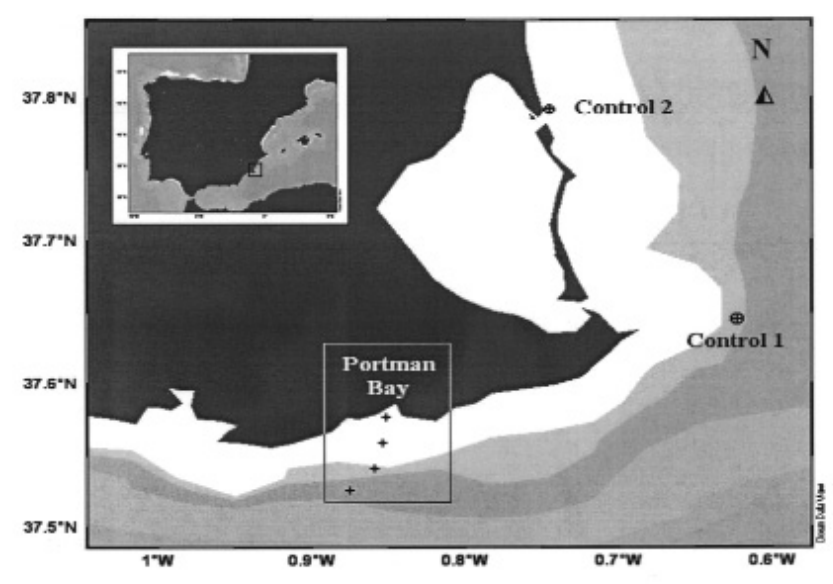

FIG. 1. - Geographic location of Portmán Bay on the Iberian Peninsula and the position of the sampling and control stations.

metal pollution in Portmán Bay (Fig. 1). The transect comprised four stations at increasing distances and depths (10, 40, 70 and $80 \mathrm{~m}$ depth), from the abandoned mine discharge points into the bay. The two control stations were located off Hormigas Island marine reserve (Control 1) and San Pedro natural reserve (Control 2). Samples were collected using a Reineck box corer. The top $3 \mathrm{~cm}$ of superficial sediment was transferred from the grab to airfree containers and held on ice in the dark during transport to the laboratory. Each sediment sample was divided into subsamples to prepare the respective treatments (porewater, elutriate and sedimentwater interface). Sediments were stored at $4^{\circ} \mathrm{C}$ in the dark for no longer than 7 days prior to toxicity testing. Sediment porewater was extracted by centrifugation $(3500 \mathrm{rpm})$, for $10 \mathrm{~min}$ at $4^{\circ} \mathrm{C}$. After extraction, porewater samples were kept at $4^{\circ} \mathrm{C}$ for no longer than $24 \mathrm{~h}$ prior to initiating toxicity testing. The control water and dilution water used in the experiments consisted of natural seawater (38 psu) collected in unpolluted areas (where the sea urchins were also collected) and filtered through a GFC Whatman ${ }^{\circledR}$ filter. Sample containers for sediment chemistry, total organic carbon, and grain size analyses were stored frozen $\left(-20^{\circ} \mathrm{C}\right)$.

\section{Toxicity testing}

\section{Amphipod toxicity tests}

The amphipods Gammarus aequicauda (Martinov, 1931) and Microdeutopus gryllotalpa (A. Costa, 1853) were collected from saline coastal lakes in Santa Pola and San Pedro Natural reserves, Southeast Spain, using a $0.5 \mathrm{~mm}$ sieve and placed in 
polyethylene buckets containing algal species, water and sediment from the collection site. Large predators were discarded. The amphipods were immediately transported in constant-temperature containers to the laboratory, where they were maintained in glass aquaria with filtered natural seawater (GFC Whatman ${ }^{\circledR}$ ) under constant aeration. Their food supply consisted of Purina ${ }^{\circledR}$ Rabbit Chow and Tetra$\mathrm{Min}^{\circledR}$ fish food (mixed 1:1). Prior to testing (December 1999), the amphipods were gradually acclimated to the test conditions for $72 \mathrm{~h}$ and then randomly selected for sediment assays. Ten individuals, 3 to 5 $\mathrm{mm}$ in length, were selected for each replicated test chamber. Amphipods were excluded if they were gravid females or in noticeably poor health. Sediment samples were placed in 1 liter polyethylene beakers one day before the amphipods were added, using guidelines described in EPA and ASTM (U.S. EPA, 1994; ASTM, 1997). Ten amphipods were exposed to $150 \mathrm{ml}$ of sediments with $600 \mathrm{ml}$ of filtered seawater. A static acute 10 day toxicity test was conducted with five replicates per treatment. Tests were maintained in constant conditions of $20^{\circ} \mathrm{C}$ and 1000 lux 16:8 h light: dark photoperiod, in a culture chamber (ASL - Snijders). The amphipods were not fed during the exposure period. A continuous airflow of approximately two bubbles per second was provided by air pumps and capillary tubing. The number of survivors in each chamber was examined at the end of the exposure period. Concurrent with each toxicity test, every lot of amphipods was evaluated for three reference toxicants: ammonium chloride $\left(\mathrm{NH}_{4} \mathrm{Cl}\right)$, potassium dichromate $\left(\mathrm{K}_{2} \mathrm{Cr}_{2} \mathrm{O}_{7}\right)$ and sodium dodecyl sulfate $\left(\mathrm{C}_{12} \mathrm{H}_{25} \mathrm{NaSO}_{4}\right)$, following ASTM (1997), and U.S. EPA (1994), protocols. Six concentrations and one seawater control were used for each test. The results of a preliminary test were used to set the definitive concentrations of each substance. Four replicates were prepared per concentration using 1 liter polyethylene vessels containing $400 \mathrm{ml}$ solution, and ten organisms were added to each replicate. All static acute tests were of 48-h duration with no food added; the number of dead animals was counted at the end of the test.

\section{Sea urchin embryo-larval toxicity test}

Adults of the sea urchin species Arbacia lixula (Linnaeus, 1758), Paracentrotus lividus (Lamarck, 1816) and Sphaerechinus granularis (Lamarck, 1816), were obtained by SCUBA divers in Aguilas
(Murcia, Spain). The sea urchins were transported to the laboratory immediately in constant-temperature containers covered with macroalgae. In the laboratory, sea urchins were maintained in glass aquaria with filtered (GFC Whatman ${ }^{\circledR}$ ) natural seawater, which was constantly renewed (approximately $501 \mathrm{~min}^{-1}$ ). They received a daily algal food supply collected at the same sampling sites. Short-term chronic toxicity tests were performed in October 2000 with the sea urchins in accordance with slightly adapted guidelines (U.S. EPA, 1995; Environment Canada, 1997; CETESB, 1999). For exposure to the sediment-water interface, $2 \mathrm{ml}$ of whole-sediment sample were introduced into each test tube through a $5 \mathrm{ml}$ syringe (with the tip cut) and $8 \mathrm{ml}$ of dilution seawater were introduced carefully to minimize resuspension. New sterilized syringes were used for each sample and rinsed with dilution seawater. Test tubes were allowed to stabilize for $24 \mathrm{~h}$ and then a filter $(\varnothing 15$ mm - GFC Whatman ${ }^{\circledR}$ filter) was placed over the sediment (Fig. 2). The same method was used for elutriate exposures, mixing $2 \mathrm{ml}$ of whole-sediment sample with $8 \mathrm{ml}$ dilution seawater $(1$ sediment / 4 seawater). After vigorous shaking (5 min), the tubes were allowed to stabilize for $24 \mathrm{~h}$, after which a permeable membrane was placed on the sediment inside the test tubes with the aid of a clean glass rod. Adult female and male urchins were stimulated to spawn with a mild electric shock $(35 \mathrm{~V})$ and the gametes were collected separately. Eggs were collected in 200 $\mathrm{ml}$ beakers containing dilution seawater and sperm was collected directly from the sea urchin gonopore with a micropipette and held on ice until egg fertilization. The organisms were allowed to spawn for up to a maximum of $10 \mathrm{~min}$, during which time careful observations were made of the amount of released gametes, their color, and the overall behavior of the spawners. Animals providing relatively little or

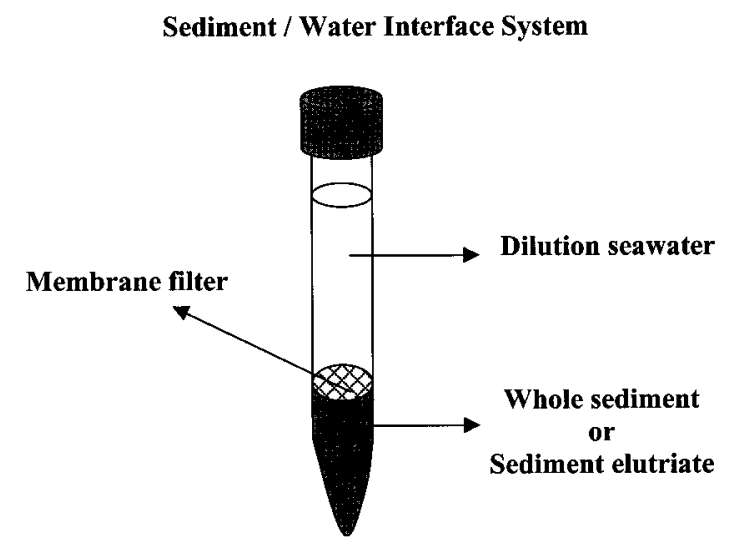

FIG. 2. - Whole sediment and elutriate-water interface systems. 
dilute gametes were excluded from testing. Each batch of eggs was observed under a microscope in a Sedgwick-Rafter cell and eggs showing abnormalities were discarded. The selected egg batches were then filtered through a $250 \mu \mathrm{m}$ screen to remove pellets and pooled in a beaker containing $400 \mathrm{ml}$ dilution seawater. Eggs were washed three times by decantation, removing the supernatant and adding dilution seawater. Gametes obtained from at least two or three organisms of each sex were combined and their densities determined. A standard sperm solution was prepared by adding $0.5 \mathrm{ml}$ of sperm to $24.5 \mathrm{ml}$ of dilution seawater. At the beginning of the study, pre-trial testing was conducted in order to determine the fecundation ratio and only rates higher than $90 \%$ were employed. The volume of solution added to the test tubes for each experiment was calculated according to the desired number of organisms required, approximately 400 fertilized eggs being added to each test chamber. This volume did not exceed $100 \mu \mathrm{l}$. Test chambers consisted of sterilized $15 \mathrm{ml}$ polystyrene centrifuge tubes. Four replicates were used per sediment treatment and three replicates in the reference toxicant tests. Tests were maintained at $20 \pm 2^{\circ} \mathrm{C}$, with a (1000 lux) $16 \mathrm{~h}$ light: $8 \mathrm{~h}$ dark photoperiod in a culture chamber (ASL Snijders). The exposure period varied from $28 \mathrm{~h}$ for P. lividus and to $38 \mathrm{~h}$ for A. lixula and S. granularis. The tests finished when at least $80 \%$ control embryos reached the normal pluteus larvae stage, each test tube being fixed with $10 \%$ buffered formalin to terminate the embryo development process and to preserve the samples. Larvae were counted under a microscope in a Sedgewick-Rafter cell, calculating the normal/abnormal ratio for the first 100 embryos encountered in each tube. Simultaneous with the toxicity test, every lot of sea urchins was tested with four reference toxicants: ammonium chloride $\left(\mathrm{NH}_{4} \mathrm{Cl}\right)$, cadmium chloride $\left(\mathrm{CdCl}_{2}\right)$, sodium dodecyl sulfate $\left(\mathrm{C}_{12} \mathrm{H}_{25} \mathrm{NaSO}_{4}\right)$ and zinc sulfate $\left(\mathrm{ZnSO}_{4}\right)$, in accordance with accepted guidelines (U.S. EPA, 1995; Environment Canada, 1997 and CETESB, 1999). The results of a preliminary test were used to set the definitive concentrations of each substance. Six concentrations and one seawater control were used for each test. Three replicates were prepared per concentration, using $15 \mathrm{ml}$ polyethylene sterilized centrifuge tubes containing $10 \mathrm{ml}$ solution, to which 400 embryos were added. All short-term chronic tests were of 28 to $38 \mathrm{~h}$ duration according to the species, and the number of normally developed embryos was counted at the end of the test.

\section{Statistical analysis}

Statistical analyses of amphipod and sea urchins tests in sediments (sediment-water interface, porewater and elutriate) were performed with the Toxstat $^{\circledR}$ statistical software (Gulley et al., 1991). Significant differences were evaluated with a parametric analysis of variance (ANOVA), followed by Dunnet's test. Data were checked for normality and homogeneity of variances with Shapiro-Wilk's and Bartlett's test, respectively. Survival and normally developed data were arc sine square root transformed when necessary prior to statistical analyses. As an estimate of relative lethal toxicity, 48-h EC50 values and their respective $95 \%$ confidence limits were calculated for all substances using the Trimmed Spearman-Karber method with Abbott's correction (Hamilton et al., 1977). The NewmanKeuls test was also applied for comparison of the means of survival obtained in the two surveys. The IC25 and IC50 of sea urchins were calculated using the Linear Interpolation Method (U.S. EPA, 1993).

\section{Physical and chemical analysis}

Grain size distribution was determined by difractometry techniques to determine particle size in sand, silt and clay fractions. The organic matter content was determined by drying at $70^{\circ} \mathrm{C}$ for $48 \mathrm{~h}$ followed by incineration at $450^{\circ} \mathrm{C}$ for $48 \mathrm{~h}$. At the beginning and the end of every test the overlying water quality parameters including temperature, salinity, dissolved oxygen, $\mathrm{pH}$ and ammonium content were measured to ensure the acceptability of the tests, following standard methods (APHA, 1995; Buchanan, 1984). The concentration of $\mathrm{NH}_{3}$ was calculated from the total $\mathrm{NH}_{4}$ concentration, $\mathrm{pH}$, temperature and salinity of each sample.

\section{RESULTS}

\section{Amphipod toxicity tests}

The sediments of Portmán Bay adversely affected both species to a similar extent (Fig. 3 and Table 1 ), with higher survival rates being recorded in deeper sites $(40-80 \mathrm{~m})$ than in shallow sites $(10 \mathrm{~m})$. Survival in the whole sediment control tests was greater than $80 \%$, and no significant differences were found between the control sites. Although Microdeutopus gryllotalpa presented higher sensi- 


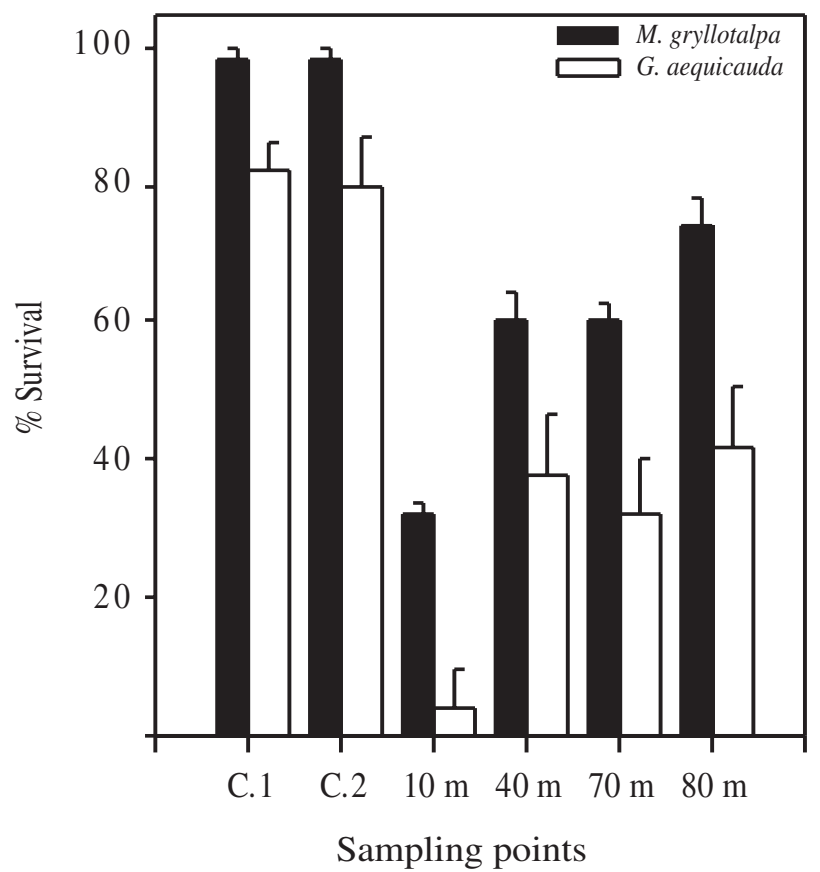

FIG. 3. - Survival percentages of Gammarus aequicauda and Microdeutopus gryllotalpa in the second survey of the whole sediment toxicity tests along the depth gradient in Portmán Bay (mean values per station with standard error).

TABLE 1. - Summary of the toxicity tests for the two surveys. Treatments not underlined by the same line indicate significant difference at $\mathrm{p}<0.05$ (Newman-Keuls test)

Contr. Ref. Point 4 Point 2 Point 3 Point 1

\begin{tabular}{|c|c|c|c|c|c|c|}
\hline $\begin{array}{l}\text { Survey } 1 \\
\% \text { survival }\end{array}$ & $95 \%$ & $91 \%$ & $52 \%$ & $42 \%$ & $42 \%$ & $15 \%$ \\
\hline $\begin{array}{l}\text { Survey } 2 \\
\% \text { survival }\end{array}$ & $82 \%$ & $80 \%$ & $42 \%$ & $38 \%$ & $32 \%$ & $4 \%$ \\
\hline
\end{tabular}

tivity to the individual reference substances, Gammarus aequicauda was the most sensitive species to the sediment of the study area. A comparison of the different sampling points in two surveys for $G$. aequicauda can be seen in Table 1, where the survival data are grouped according to significant differences. The results reflect the increase in toxicity the nearer the sampling point is to the outlet. There were significant differences along the pollution gradient (one-way ANOVA; $\mathrm{p}<0.05$ ). The effective concentrations (EC50, $48 \mathrm{~h}$ ) for G. aequicauda were $49.6 \pm 5.6 \mathrm{mg} \mathrm{l}^{-1}$ in the case of ammonium chloride, $9.5 \pm 2.1 \mathrm{mg} \mathrm{l}^{-1}$ for potassium dichromate and $5.4 \pm 0.3$ $\mathrm{mg} \mathrm{l}^{-1}$ for sodium dodecyl sulfate (Fig. 4). The effective concentrations for $M$. gryllotapa were lower: $35.5 \pm 5.6 \mathrm{mg} \mathrm{l}^{-1}$ for ammonium chloride, $6.5 \pm 0.3 \mathrm{mg}$ $\mathrm{l}^{-1}$ for potassium dichromate of and $2.9 \pm 0.2 \mathrm{mg} \mathrm{l}^{-1}$ for sodium dodecyl sulfate (Fig. 4).

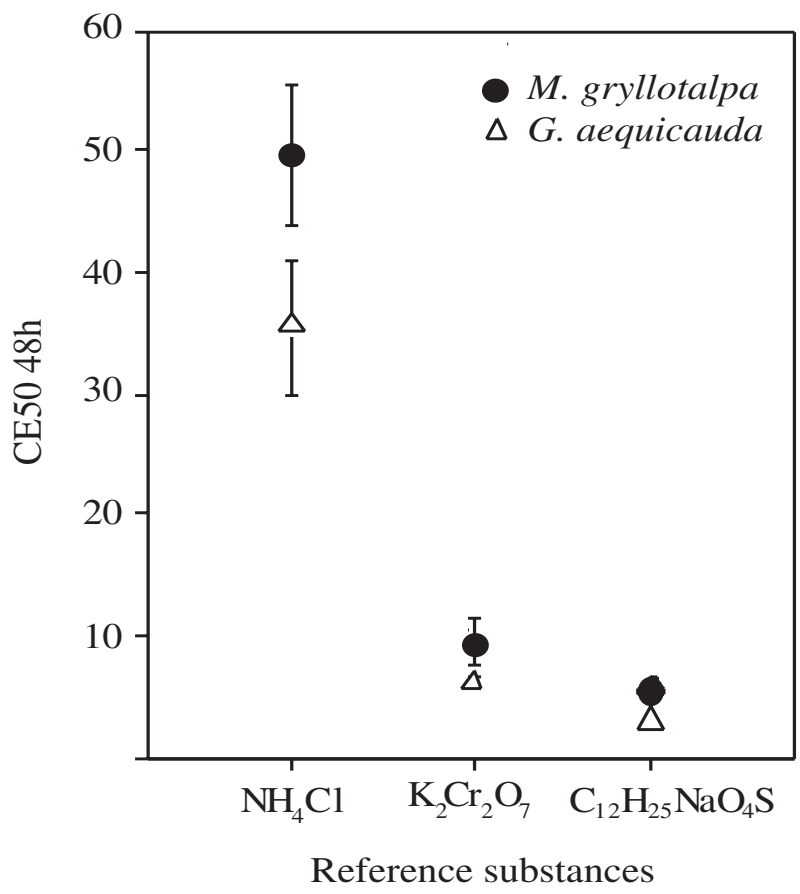

FIG. 4. - Amphipod reference toxicants tests: ammonium chloride $\left(\mathrm{NH}_{4} \mathrm{Cl}\right)$, sodium dodecyl sulfate $\left(\mathrm{C}_{12} \mathrm{H}_{25} \mathrm{NaSO}_{4}\right)$ and potassium dichromate $\left(\mathrm{K}_{2} \mathrm{Cr}_{2} \mathrm{O}_{7}\right)$.

\section{Sea urchin embryo-larval toxicity tests}

Each sediment treatment (sediment porewater, sediment elutriate and sediment-water interface) had a significantly (ANOVA; $p<0.05$ ) adverse effect on all the sea urchin species tested, the porewater showing higher toxicity levels than the elutriate and sediment (Figs. 5, 6 and 7). The sensitivity of embryolarval sea urchin tests was similar for all three species, Arbacia lixula, Paracentrotus lividus and Sphaerechinus granularis (Figs. 5, 6 and 7). The IC25 and IC50 for the reference toxicants, ammonium chloride, cadmium chloride, sodium dodecyl sulfate and zinc sulfate, were similar for all three sea urchin species (Table 2), though zinc sulfate was slightly more toxic than the other four chemicals, the sensitivity of these Mediterranean species being similar to the sensitivity of other species of sea urchins found in the literature (ASTM, 1997; USEPA, 1994; Kobayashi, 1984). The larval response to dodecyl sulfate was very uniform in the three sea urchin species, with a low standard error.

\section{Physical and chemical analysis}

The grain size along the transect of Portmán Bay was affected by the mining activities. While control sediments were muddy sands, the sediments from 


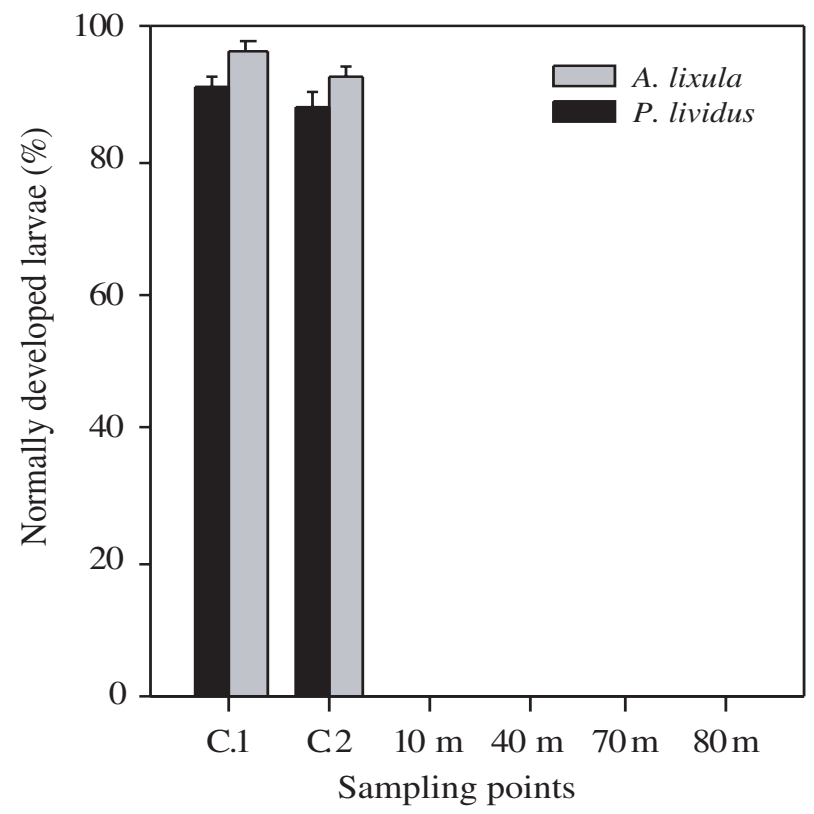

FIG. 5. - Porewater tests: comparison of mean percentage of normally developed larvae ( \pm standard error) of Arbacia lixula and Paracentrotus lividus at the different sampling points.

Portmán Bay were muddy, except in the shallow sampling station $(10 \mathrm{~m})$, where coarse sands predominated (Table 3). Almost all the samples had a considerable organic matter content (Table 3). Water quality data (temperature, dissolved oxygen, salinity, $\mathrm{pH}$ and ammonium), were constant and within acceptable limits during the experiments, except that ammonium values were high in the porewater and elutriate exposures (Table 3). Zinc, lead and cadmium were found in high concentrations along the pollution gradient of Portmán Bay and were statistically correlated with amphipod and sea urchin larvae toxicity levels.

\section{DISCUSSION}

Amphipods have been routinely used to evaluate sediment toxicity because of their sensitivity to many sediment-associated pollutants, short generation time, ease of culture in the laboratory, tolerance to a wide range of sediment physicochemical characteristics, and because they live in direct contact with the sediment. Although several standard methods have been developed for assessing the toxicity of sediment-associated pollutants using amphipod species from the Atlantic and Pacific coasts of North America, no such tests have been reported for use in Europe, more specifically in the Mediterranean. The USA and Canada have recognized toxicity guide-

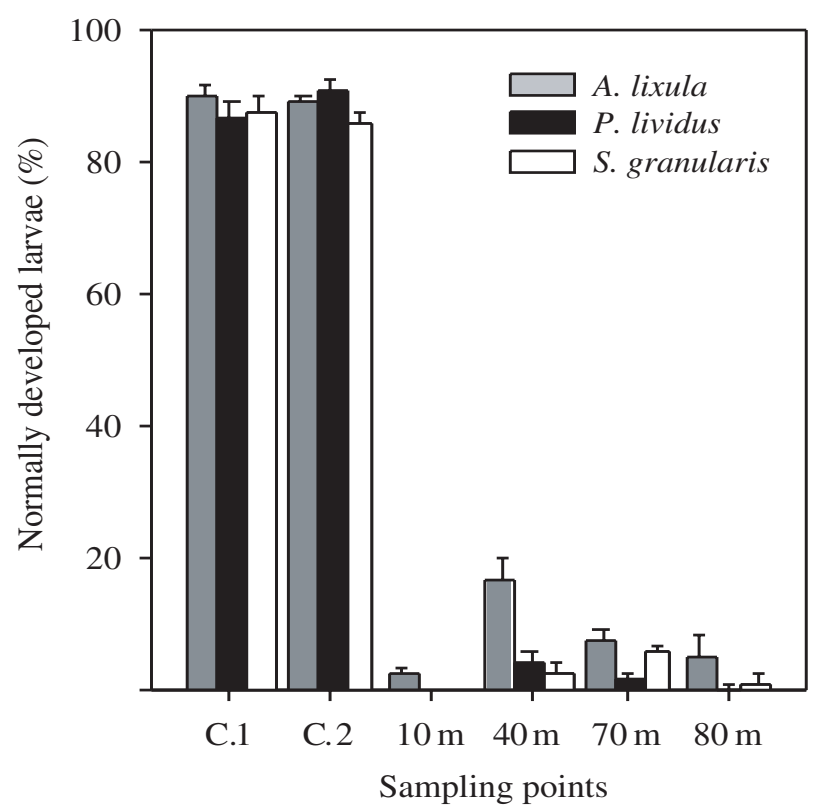

FIG. 6. - Elutriate-water interface tests: comparison of mean percentage of normally developed larvae ( \pm standard error) of Arbacia lixula, Paracentrotus lividus and Sphaerechinus granularis at the different sampling points.

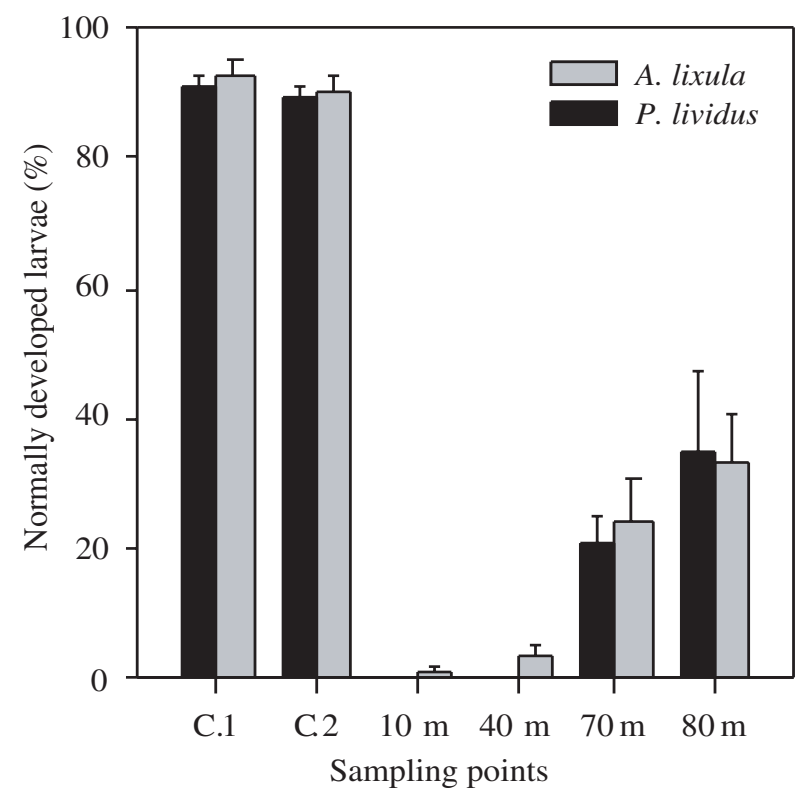

FIG. 7. - Sediment-water interface tests: comparison of mean percentage of normally developed larvae ( \pm standard error) of Arbacia lixula and Paracentrotus lividus at the different sampling points.

lines for sediment quality assessment. The results of the present study indicate that the tests using Gammarus aequicauda and Microdeutopus gryllotalpa are suitable for sediment toxicity determinations in the Mediterranean Sea, since such tests clearly identified an environmental gradient of highly degraded communities in Portmán Bay. The assessment of sediment quality generally involves an evaluation of 
TABLE 2. - Average ICp50 and ICp25 concentrations (mg $\left.\mathrm{l}^{-1}\right)$ and associated standard deviation $( \pm)$ of the reference substances for the sea urchin species.

\begin{tabular}{|c|c|c|c|c|c|c|}
\hline \multirow{2}{*}{$\begin{array}{l}\text { Reference } \\
\text { substances }\end{array}$} & \multicolumn{2}{|c|}{ A. lixula } & \multicolumn{2}{|c|}{ P. lividus } & \multicolumn{2}{|c|}{ S. granularis } \\
\hline & ICp50 & ICp25 & ICp50 & ICp 25 & ICp50 & ICp25 \\
\hline $\mathrm{NH}_{4} \mathrm{Cl}$ & $2.56 \pm 0.46$ & $1.70 \pm 0.49$ & $2.72 \pm 0.10$ & $1.80 \pm 0.31$ & $2.30 \pm 0.36$ & $1.71 \pm 0.45$ \\
\hline $\mathrm{CdCl}_{2}$ & $2.06 \pm 0.62$ & $1.08 \pm 0.22$ & $2.18 \pm 0.17$ & $1.16 \pm 0.38$ & $2.08 \pm 0.45$ & $1.04 \pm 0.04$ \\
\hline $\mathrm{C}_{12} \mathrm{H}_{25} \mathrm{NaO}_{4} \mathrm{~S}$ & $1.55 \pm 0.17$ & $1.10 \pm 0.18$ & $1.48 \pm 0.34$ & $1.04 \pm 0.14$ & $1.59 \pm 0.22$ & $1.13 \pm 0.14$ \\
\hline $\mathrm{ZnSO}_{4}$ & $0.04 \pm 0.01$ & $0.03 \pm 0.01$ & $0.05 \pm 0.01$ & $0.03 \pm 0.01$ & $0.06 \pm 0.01$ & $0.03 \pm 0.01$ \\
\hline
\end{tabular}

TABLE 3. - Physical and chemical characteristics of Portmán Bay and reference sediments (metal levels in sediment by Guerrero and Rodríguez, 1990). SWIa, sediment-water interface; PWb, porewater; NDc, not determined.

\begin{tabular}{|c|c|c|c|c|c|c|c|c|}
\hline \multirow[t]{2}{*}{ Stations } & \multirow[b]{2}{*}{ SWIa } & \multirow{2}{*}{$\begin{array}{c}\text { Ammomium } \\
\left(\mathrm{NH}_{3} \mathrm{mg} \mathrm{l}^{-1}\right) \\
\mathrm{PWb}\end{array}$} & \multirow[b]{2}{*}{ Elutriate } & \multirow[t]{2}{*}{$\begin{array}{c}\text { Organic Matter } \\
(\%)\end{array}$} & \multirow[t]{2}{*}{$\begin{array}{c}\text { Particles } \\
<63 \mu \mathrm{m}(\%)\end{array}$} & \multicolumn{3}{|c|}{$\begin{array}{c}\text { Pollutants } \\
\text { ( } \mu \mathrm{g} \mathrm{g}^{-1} \text { dry wt of sediments) }\end{array}$} \\
\hline & & & & & & $\mathrm{Cd}$ & $\mathrm{Pb}$ & $\mathrm{Zn}$ \\
\hline Control 1 & 0.015 & 0.023 & 0.020 & 4.01 & 8.26 & 0.01 & 0.1 & 0.1 \\
\hline Control 2 & 0.019 & NDc & NDc & 5.00 & 3.83 & 0.01 & 0.1 & 0.1 \\
\hline Portmán 10 m & 0.052 & 1.202 & 0.066 & 6.64 & 8.18 & 6.25 & 1182 & 5.093 \\
\hline Portmán 40 m & 0.028 & 3.928 & 0.036 & 6.60 & 51.68 & 3.32 & 537 & 681 \\
\hline Portmán 70 m & 0.025 & 1.805 & 0.061 & 7.88 & 41.95 & 0.39 & 165 & 262 \\
\hline Portmán 80 m & 0.035 & 6.284 & 0.093 & 15.23 & 54.76 & 0.25 & 141 & 163 \\
\hline
\end{tabular}

solid-phase sediments, although porewater is also important, because it represents a major route of exposure to benthic organisms (Whiteman et al., 1996; Carr et al., 1989; Adams et al., 1985) and substantially influences the bioavailability of pollutants (Carr et al., 1996a; Ankley et al., 1994; Di Toro et al., 1991; Carr et al. 2001).

The sediment-water interface tests and reference toxicant tests on sea urchins had a similar effect to the amphipod tests, but the sea urchins showed greater sensitivity in all the experiments and were more effective in other ways too; for example, they gave a response more rapidly and at lower cost. Sea urchins take up less space and may be useful for low to moderate toxicity testing. The sediments from Portmán Bay, which are strongly polluted by heavy metals, had a significant $(\mathrm{p}<0.05)$ harmful effect on all the species of amphipods and sea urchins studied. Sea urchin larvae showed greater sensitivity than amphipods, although both were more seriously affected in the shallower points studied. The sensitivity of both amphipod species was similar, pointing to a toxicity gradient from the outlet to deeper sampling points. The effect of reference toxicants on both Mediterranean amphipod species used was similar to that recorded for species found in the bibliography. In all the whole sediment-water interface and reference toxicant tests sea urchins showed greater sensitivity. The sediment-water interface provided more realistic exposure conditions for epibenthic embryo-larval test organisms and these experiments tended to minimize interferences from porewater constituents, including ammonia and hydrogen sulfide (Hunt et al., 2001a). This methodology has great potential for the evaluation and characterization of marine pollution, supplementing traditional toxicity tests carried out with echinoderms. Porewater and elutriate tests caused practically $100 \%$ larval mortality in all the polluted sediments due to the presence of ammonium and heavy metals in concentrations which exceeded larval tolerance. The toxicity of aqueous ammonia solution to many aquatic organisms is primarily attributed to the to the $\mathrm{NH}_{3}$ (un-ionized) species, with the ammonium ion (ionized) species being relatively less toxic (Armstrong et al., 1978; Thurston and Russo, 1981; Sarda and Burton, 1995). These tests suggest that soft and hard benthic communities from Portmán Bay would be prone to high toxicity during storm events that disturb deep sediments. The use of water column organisms such as sea urchin larvae for porewater toxicity has been recommended for understanding potential biological impact (Adams et al., 1985). A comparison of the sensitivity to chemical substances of marine organisms representative of the water column and benthic species (epibenthic and burrowing), showed that the sensitivity of planktonic species is similar to that of epibenthic species and higher than that of burrowing species (Zarba, 1992; Nagell et al., 1974).

The tests we describe were carried our ten years after the mine ceased its activity. A recent project for 
reclaiming Portmán Bay has been turned down by the European Commission. This study has confirmed that the dredging of shallow sediments may produce acute or chronic toxicity to marine invertebrates if they are re-suspended, the resulting level of toxicity having significant potential for harming local marine ecosystems.

\section{ACKNOWLEDGEMENTS}

This study was funded by a grant from MUTISAECI (Agencia Española de Cooperación Internacional) of the Spanish Government and by the project ACU00-012-C2-2 of the Spanish Commission of Science an Technology (CICYT). We thank José Benedito, Carmen Rodríguez and Julio Más from the Spanish Institute of Oceanography for assistance with sampling and Philip Thomas for help in preparing the English version.

\section{REFERENCES}

Adams, W.J., R.A. Kimerle and R.G. Mosher. - 1985. Aquatic safety assessment of chemicals sorbed to sediments. In: R.D. Cardwell, R. Purdy and R.C. Bahner (eds.), Aquatic toxicology and hazard assessment: Seventh symposium. Philadelphia (PA): ASTM.STP, pp. 429-453.

Anderson, B.S., J.W. Hunt., M.M. Hester and B.M. Phillips. - 1996. Assessment of sediment toxicity at the sediment-water interface. In: Ostrader (ed.), Techniques in Aquatic Toxicology, pp. 609-624. Lewis, Boca Raton, FL, USA.

Ankley, G.T., N.A. Tomas., D.M. Di Toro and others. - 1994. Assessing potential bioavailability of metals in sediments: A proposed approach. Environ. Management, 18: 331-337.

American Public Health Association, American Water Works Association, and Water Pollution Control Federation. - 1995. Standard Methods, 18th ed. American Public Health Association, Washington, DC

American Society for Testing and Materials. - 1997. Standard guide for conducting 10-day static sediment toxicity tests with marine and estuarine amphipods. E1367-92. In: Annual Book of ASTM Standards, 11.05. Philadelphia, PA, pp. 731-756.

Armstrong, D.A., D. Cippendale, A.W. Knght and J.L. Colt. -1978. Interaction of ionized and un-ionized ammonia on short term survival and growth of spraw larvae, Macrobrachium rosenbergii. Biol. Bull., 154: 15-31.

Bryn M.P., S.A. Brian and J.W. Hunt. - 1998. Spatial and temporal variation in results of purple urchin (Strongylocentrotus purpuratus) toxicity tests with Zinc. Environ. Toxicol. Chem., 17: 453-459.

Buchanan, J.B. - 1984. Sediment analysis. In: N.A. Holme and A.D. Mcintyre (eds.), Methods for the study of marine benthos, pp. 41-65. Blackwell, Cambridge

Carr, R.S., J.W. Williams and C.T.B. Fragata. - 1989. Development and evaluation of a novel marine sediment porewater toxicity test with the polychaete Dinophilus gyrociliatus. Environ. Toxicol. Chem., 8: 533-543.

Carr R.S., D.C. Chapman., B.J. Presley., J.M. Biedenbach., L. Robertson., P. Boothe., R. Kilada., T. Wade and P. Montagna. - 1996a. Sediment porewater toxicity assessment studies in the vicinity of offshore oil and gas production plataforms in the Gulf of Mexico. Can. J. Fish Aquat. Sci., 53: 2618-2628.

Carr, R.S., E.R. Long., H.L. Windom., D.C. Chapman., G. Thursby., G.M. Sloane and D.A. Wolf. - 1996b. Sediment quality assessment studies of Tampa Bay, Florida. Environ. Toxicol Chem., 15: 1218-1231

Carr, R.S., M. Nipper., W.J. Adams., W.J. Berry., G.A. Burton Jr., K. Ho., D. MacDonald., R. Scroggins and P.V. Winger. - 2001. Summary of a SETAC techical workshop: Porewater toxicity testing: Biological, chemical and ecological considerations with a review of methods and applications, and recommendations for future areas of research. Pensacola, FL. Society of Environ. Toxicol. Chem., $38 \mathrm{pp}$

Cesar, A., L. Marín, R. Vita, M. Gomez, B. Jiménez and A. Marín. - 2000. Test de toxicidad con sedimento marino en la costa mediterránea empleando anfípodos: Gammarus aequicauda y Microdeutopus gryllotalpa. In: G. Espíndola; R. Paschoal; O. Rocha; C. Bohrer and L. Neto (eds.), Ecotoxicologia: Perspectivas para o século XXI, pp.17-27. São Carlos, RiMa.

CETESB. - 1999. Método de ensaio: Água do mar - Teste de toxicidade crônica de curta duração com Lytechinus variegatus, Lamarck,1816 (Echinodermata: Echinoidea). L5.250. Cia. de Tecnologia de Saneamento Ambiental do Estado de São Paulo, Brasil., 22 pp.

Chapman, P.M. - 1996. Presentation and interpretation of sediment quality triad data. Ecotoxicology, 5: 327-339.

Del Valls, T.A., J.M. Forja and A. Gómez-Parra. - 1998. Integrated assessment of sediment quality in two littoral ecosystems from the gulf of Cádiz, Spain. Environ. Toxicol. Chem., 17: 1073-1084.

Di Toro, D.M., C.S. Zarba., D.J. Hansen., W.J. Berry., R.C Swartz., C.E. Cowan., S.P. Pavlou., H.E. Allen., N.A. Tomas. and P.R. Paquin. - 1991. Technical basis for establishing sediment quality criteria for nonionic organic chemicals using equilibrium partitioning. Environ. Toxicol. Chem. 10: 1541-1583.

Environment Canada. - 1992. Biological test method: Fertilization assay using echinoids (sea urchins and sand dollars), amended November 1997. EPS 1/RM/27. North Vancouver, BC., 97 pp.

Gannon, J.E. and A.M. Beeton. - 1971. Procedures for determining the effects of dredge sediments on biota - benthos viability and sediment selectivity tests. J. Wat. Pollut. Control Fed., 43: 392-389.

Gulley, D., A.M. Boelter and H. L. Bergman. - 1991. TOXSTAT ${ }^{\circledR}$ Computer Program, Version 3.3. University of Wyoming, Laramie, WY.

Hamilton, M.A., R.C. Russo and R.V. Thurston.- 1977. Trimmed Spearman-Karber method for estimating median lethal concentrations in toxicological bioassays. Envir. Sci. Technol. 11: 714719; correction 12: $417 ; 1978$.

Hunt, J.W., B.S. Anderson., B.M. Phillips., R.S. Tjeerdema., K.M. Taberski., C.J. Wilson., H.M. Puckett., M. Stephenson., R. Fairey and J. Oakden. - 2001. A large-scale categorization of sites in San Francisco Bay, USA, based on the sediment quality triad, toxicity identification evaluations, and gradient studies. Environ. Toxicol. Chem. 20: 1252-1265.

Hunt, J.W., B.S. Anderson., B.M. Phillips., J. Newman., R.S Tjeerdema., R. Fairey, H.M. Puckett., M. Stephenson, R.W. Smith., C.J. Wilson and K.M. Taberski. - 2001. Evaluation and use of sediment toxicity reference sites for statistical comparisons in regional assessments. Environ. Toxicol. Chem., 20: $1266-1275$

Ingersoll, C.G. - 1995. Sediment Tests. In: Gary M. Rand (ed.), Fundamentals of Aquatic Toxicology, pp. 231-255. Taylor \& Francis, USA.

Kobayashi, N. - 1984. Marine ecotoxicological testing in echinoderms. In: G. Persoone., E. Jaspers. and C. Claus (eds.), Ecotoxicological Testing for the Marine Environment, pp. 341381. Bredene, Belgium.

Nagell, B.; M. Notini. and O. Grahn. - 1974. Toxicity of four oil dispersants to some animals from the Baltic Sea. Mar. Biol., 28: 237-243.

Nipper, M.G., V.A. Prósperi and A.J. Zamboni. - 1993. Toxicity testing with coastal species of southeastern Brazil. Echinoderm Sperm and Embryos. Environ. Contamin. Toxicol., 50: 646-652.

Sarda, N. and G.A. Burton Jr. - 1995. Ammonia variation in sediments: spatial, temporal and method-related effects. Environ. Contamin. Toxicol., 14: 1499-1506.

Swartz, R.C, W.A. DeBen, K.A. Sercu. and J.O. Lamberson. 1982. Sediment toxicity and the distribution of the amphipods in Commencement Bay, Washington, USA. Mar. Pol. Bull., 13: 359-364. 
Thurston, R.V. and R.C. Russo. - 1981. Ammonia toxicity to fishes: Effect of $\mathrm{pH}$ on the toxicity of the un-ionized ammonia species. Environ. Sci. Technol., 15: 837-840.

U.S. Environmental Protection Agence. - 1994. Methods for assessing the toxicity of sediment-associated pollutants with estuarine and marine amphipods. EPA/600/-94/025.

U.S. Environmental Protection Agency. - 1995. Short-term methods for estimating the chronic toxicity of effluents and receiving waters to west coast marine and estuarine organisms. EPA/ 600/ R-95-136. Cincinnati, Ohio.

U.S. Environmental Protection Agency. - 1993. A Linear Interpolation Method for Sublethal Toxicity: The Inhibition Concentration (ICp) Approach. Duluth, MN 55804

Van Den Berg, G.A., J.P.G. Loch., L.M. Van Der Heijdt and J.J.G. Zwolsman. - 1998. Vertical distribution of acid-volatile sulfide and simultaneosly extracted metals in a recent sedimentation area of the river Muese in the Netherlands. Environ. Toxicol. Chem., 17: 758-763.

Weber, C. I., W.B. Horning., D.J. Klemm., T.W. Neiheiselm., P.A. Lewis., E.L. Robinson., J. Menkedick. and F. Kessler. - 1988. Short-term methods for estimating the chronic toxicity of effluents and receiving waters to marine and estuarine organisms. EPA-600/4-87/028, 417 pp.

Whiteman, F.M., G. T. Ankley., M.D. Kahl., D.M. Rau. and M.D. Bacer. - 1996. Evaluation of interstitial water as route of exposure for ammonia in sediment tests with benthic macroinvertebrates. Environ. Toxicol. Chem., 15: 794-801.

Zarba, C. - 1992. Equilibrium partitioning approach. In: USEPA (eds.), Sediment classification methods compendium. 6:6-1-610. Washington, D.C.: Environmental Protection Agency. 
